\title{
De Luitenant-Civil van de Indaginghe te Gent en te Dendermonde \\ Vorstelijke rechtbanken voor verbintenissen in Vlaanderen (16e-18e Eeuw)
}

\section{P. LENDERS*}

Over sommige gespecialiseerde rechtbanken - ook vorstelijke - is niet altijd veel geweten, vooral niet zo deze een beperkte opdracht bezaten en binnen een welomschreven territorium functioneerden. Zo is het met de rechtbanken, die te Gent en te Dendermonde onder het gezag van LuitenantCivil van de Indaginghe werkten. Niet onmiddellijk terugwijsbaar in de bekende hiërarchische structuren worden zij - niet ten onrechte - wel eens buitengewone rechtbanken geheten zoals de Hofrechtbank, de Rechtbank van de Reninge, de Hoven van de Dode Hand in Henegouwen e.a.

De beide rechtbanken van de indaginghe - of van de dagvaarding - werden door keizer Karel V ten gerieve van de Gentse poorters opgericht en zijn een uitloper van de bestraffing van de Arteveldestad na haar opstandigheid in 1537-1540. Men kent in de andere vorstendommen geen gelijkaardige gerechtelijke instanties.

Heel veel is niet over deze rechtbanken geschreven. De Vlaamse jurist Jan Antoon Knobbaert ( $\uparrow 1677)$ schreef met heel veel bewondering over de Gentse instantie in de zeventiende eeuw ${ }^{1}$. Sindsdien is de studie van die instelling verwaarloosd. Zelfs L.P. Gachard vermeldt in zijn grote publikatie waarin hij meer dan 400 documenten over de Gentse opstand openbaar maakt, haar oprichting niet. Alexandre Henne spreekt er wel over, ook E. Defacqz in zijn bekende studie over het oude recht en natuurlijk V. Fris in zijn werk over het Gentse verleden. Anderhalf decennium geleden brachten archivarissen een

- Gebruikte afkortingen

O.P.B.: Recueil des ordonnances des Pays-Bas; Deuxieme série: 15061700. Zeven dln. (Brussel, 1893-1978). Règne des Archiducs: 1597-1621. 2 dln. (Brussel, 1909-1912).

O.P.B.A.: Recueil des ordonnances des Pays-Bas Autrichiens; Troisième série: 1700-1804. Vijftien dln. (Brussel, 1860-1942). Pl.v.Vl.: Placcaerten van Vlaenderen. Dertien dln. (Gent, 1639-1786).

1 J.A. KNOBBAERT, Jus civile Gandensium, hoc est usus moresque eorum in populo nati, a principe confirmati et observationibus illustrati. $2 e$ uitg. (Brussel, 1700), 466-472. Zie over hem E. VAN ARENBERGH in Biographie nationale, X (Brussel, 1889), 790-791. 


\section{P. LENDERS}

stereotiep beeld van de instelling en onlangs werd er in het Liber Amicorum Achilles De Vos een kleine studie aan gewijd, die inzake jurisdictie en werking niet veel nieuwe elementen aanbracht ${ }^{2}$. Van de Dendermondse evenknie werd tot nog toe geen melding gemaakt.

Als machtige en rijke stad had Gent in de middeleeuwen zijn gezag tot ver buiten de muren kunnen vestigen. Die extra-territoriale rechtsmacht gaf de schepenen van de Keure de bevoegdheid om tegen de gewone rechtsregels in mensen van buiten de stad in burgerlijke zaken te dagvaarden. Hun rechtsgebied - de "ommesaete" - besloeg een ruim deel van Vlaanderen. Zo'n extra-stedelijk machtsgebied was niet zo uitzonderlijk: zij kwam ook elders voor. Zo achtten de drie Brabantse hoofdsteden zich alleen en met uitsluiting van alle anderen bevoegd in geschillen, waarin hun poorters als aanleggers betrokken waren ${ }^{3}$.

Dit vexerende recht was al lang een doorn in het oog van de Bourgondische vorsten. Zij waren ook niet gelukkig met het feit dat de stad Gent haar eigen magistraat via commissarissen zelf aanstelde. Zij waren het nog minder met het verworven recht van deze autonome instantie, dat haar toeliet tot ver buiten de banmijl gerechtelijk gezag uit te oefenen ten nadele van de rechten van de plattelandsbewoners en hun onderworpenheid aan de heerlijke, plaatselijke of regionale rechtspraak. "In actien personele", schreef de bekende civilist Philip Wielant (1442-1520), "die heesschere moet volgen den Juge van den verweerdere". Maar hij voegde eraan toe: "De verweerdere is oock betreckelijck voor zijnen niet-Juge uyt causen van privilegiën van den heeschere" 4.

De rechtsmacht ten voordele van de Gentse poorters leek de vorst niet alleen een onrechtmatige heerschappij over de dorpen, hij was ook op de hoogte van het feit dat dit gezag meer dan eens misbruikt werd in vonnissen, die dan ten voordele van rijke, bevriende poorters geveld werden of zelfs ten voordele van eigen leden van de zetelende magistraat, die als aanlegger partij

2 L.P. GACHARD, Relation sur les troubles de Gand sous Charles Quint. (Brussel, 1846). Alleen een gepubliceerde akte van 4 juli 1542 vermeldt de luitenant-civil als deelnemer aan een verhoor - samen met de raadsfiscaal - van een verdachte van opstandige agitatie (p. 473). A. HENNE, Histoire du règne de Charles Quint, VII (Brussel-Leipzig, 1859), 113-114. E. DEFACQZ, Ancien droit belgique, I (Brussel, 1873), 110-111. V. FRIS, Histoire de Gand (Gent, 1930), 182. Het Rijksarchief in de Provinciën. Overzicht van de Fondsen en Verzamelingen. I De Vlaamse Provinciën (Brussel, 1975), 183. J. BUNTINX, De luitenant-civil van de Indaginghe van Gent. In Liber Amicorum Achilles De Vos (Evergem, 1989), 61-66.

3 R. VAN UYTVEN, Imperialisme of Zelfverdediging. De extra-stedelijke Rechtsmacht van Leuven. In Bijdragen tot de Geschiedenis, 58 (1975), 7-70.

4 Ph. WIELANT, Practijcke civile, (Antwerpen, 1573; anastatische uitg., 1968), 55-56. 


\section{DE LUITENANT-CIVIL VAN DE INDAGINGHE}

waren, en mede konden rechter zijn ${ }^{5}$. Zo hij deze toestanden oogluikend geduld had bij goede verstandhouding met de bewindvoerders van de Arteveldestad, moest deze abnormale rechtsmacht mikpunt worden van het repressief optreden bij opstandigheid. Dat gebeurde door de Carolijnse Concessie van 30 april $1540^{6}$.

Het artikel 63 zegt zeer duidelijk "lesdits bourgeois et manans de notre ville de Gand ne jouiront d'oresnavant des indaginghes et ne pourront faire adjourner ou attraire audit Gand leurs censiers et debteurs demeurans hors de ladite ville et eschevinage de Gand, ne lesdits eschevins en avoir court et connoissance, mais seront tenuz les poursuivre en premiere instance pardevant les juges de leurs résidences, ne fut que lesdits censiers et debteurs se fussent obligez et soubmis a payement du deu pardevant nosdits eschevins de Gand." Artikel 65 gaat daarover verder "Pardessus ce pour le bien, repos et tranquillité de nostredit Pays de Flandres et a fin d'éviter que lesdites divisions et commotions passées plus n'adviennent, ordonnons et déclarons que lesdits de notre ville de Gand n'ont, ny auront doresnavant jurisdiction, authorite, prééminence ne supériorité sur le Vieu-bourg de Gand, les villes et chastellenies de Courtray, Audenarde, Tenremonde, Alost, Grandmont, Nienove, quatre mestiers et Pays de Waze, et généralement tout ce que l'on avoit accoustumé dire et appeller chastellenies et quartier de Gand, lesquels sont et d̀ perpétuité demeureront séparez et distraicts desdits de Gand, sans pouvoir avoir recours d iceux, et sans que lesdits de Gand les puissent appeller ou invocquer vers eux, soit pour le faict d'aydes ou autre". De beide artikels laten aan duidelijkheid niets te wensen over. Aan de Gentse schepenbank werd alle rechtsmacht ontnomen, die zij vroeger bezat in het gebied van het huidige Oost-Vlaanderen en de streek rond Kortrijk. De ingebreke gestelden werden naar hun eigen, natuurlijke rechters verwezen; daar moesten de Gentse eisers de processen aanleggen. Verdere elementen van de bestraffing voorzagen dat de schepenbanken alleen en rechtstreeks door de vorst zouden aangesteld worden en dat de neringen alle politieke invloed zouden verliezen.

Daarmee leek de zaak afgedaan. De bestraffende regeling hield alleen rekening met politieke principes et structuren. De economische realiteit was daarbij uit het oog verloren. Die zou al vlug haar eisen stellen en te Brussel wilde men haar ontwikkeling niet verhinderen. Gent was immers een heel belangrijk regionaal economisch en financieel centrum.

5 J. BUNTINX, o.c., 61.

6 O.P.B. IV, 181-190. Cfr. ook N. MADDENS, De opstandige Houding van Gent tijdens de Regering van Keizer Karel V (1515-1540). In Oostvlaams Verbond van Kringen voor Geschiedenis. Voorlichtingsreeks, nieuwe reeks, 17 (Maldegem, 1978). 


\section{P. LENDERS}

\section{DE VORSTELIJKE VERBINTENISSENRECHTBANK TE GENT}

De politieke diminutio capitis van de stad Gent had zware gevolgen voor de talrijke zakenlieden en grootgrondbezitters, die met buitenlieden pachtcontracten en andere zakelijke regelingen afsloten, en voor de corporaties, die aan het platteland hun produkten afleverden. Voor deze economisch-actieve bovenlaag betekende de beperking van de rechtsmacht van het college van de Keure zoveel als een ramp. Bij het niet-nakomen van verplichtingen van de dorpsbewoners moest zij nauwkeurig uitzoeken onder welke rechtbanken de in-gebreke blijvenden ressorteerden en welke rechtbanken alleen voor feodale of correctionele zaken bevoegd waren en welke in burgerlijke aangelegenheden. Op het einde van het Ancien Regime telde $\mathrm{Ph}$. Van Hille in Vlaanderen meer dan 2500 rechtbanken ${ }^{7}$. Dit hoge cijfer werd weliswaar opgetekend in een periode, die ongeveer twee en een halve eeuw op de Carolijnse Concessie volgt. Toch laat het vermoeden dat circa 1540 het aantal rechtbanken ook al heel hoog geweest moet zijn.

Een bijkomend euvel bestond erin dat men van machtige dorpsheren en boeren bij ingewikkelde betwistingen moeilijk een correcte uitspraak bekwam en nog moeilijker een vlotte uitvoering van het vonnis. Op het platteland was men veel nonchalanter dan in de steden. Daarbij betekende het veroordelen of zelfs het sturen van een dagvaarding naar een vooraanstaande van het dorp of naar een bekende pachter een blijvende vijandschap. De Vlaamse jurist J.A. Knobbaert drukte in een van zijn rechtstudies daarom de wens uit dat de vorst alle lokale rechtbanken zou afschaffen en vervangen door enkele eigen rechtsprekende kamers: "Meo judicio perutile foret rei publicae, si omnis jurisdictio rusticis magistratibus auferretur, applicaturque quatuor proto-collegiis in suo respective districtu exercenda" 8 . De Franse jurist Charles Loyseau (1566-1627) wijdde zelfs een hele studie aan de plattelandsrechtbanken: "Discours sur l'abus des justices de village".

Te Brussel realiseerde men zich al heel vlug het probleem van de rechtspraak inzake verbintenissen van stedelingen. Aan de nieuwe procedure hadden de plattelandsbewoners geen boodschap: vooreerst omwille van de afkeer voor de rijke poorters, verder ook omdat het hun bij gebrek aan gevormde juristen veelal moeilijk was begrip op te brengen voor juridische spitsvondigheden en clausules. Het is in elk geval verrassend hoe vlug men op de protesten van Gent in deze aangelegenheid inging. Reeds in het begin

7 Ph. VAN HILLE, De gerechtelijke Hervorming van Keizer Jozef II. (Tielt, 1973), 14.

8 J.A. KNOBBAERT, o.c., 471. 


\section{DE LUITENANT-CIVIL VAN DE INDAGINGHE}

van het jaar dat volgde op de afkondiging van de Carolijnse Concessie werd een regeling getroffen, $\mathrm{nl}$. op 14 februari 1541 (n.s.) ${ }^{9}$.

\section{De Oprichting van de Rechtbank}

Het college van de Keure, dat de protesten van zakenlieden, eigenaars en corporaties gesteund had, kreeg niet wat het verhoopt had: het herstel van de extraterritoriale rechtsmacht. De landvoogdes en de vorstelijke raadsheren wilden het economisch leven wel zekerheid en veiligheid waarborgen, maar waren na de zware incidenten van 1537-1540 niet bereid de stad opnieuw gezag te geven over het omliggende platteland. Een compromis werd gevonden in de oprichting van een vorstelijke rechtbank te Gent met dezelfde bevoegdheid als de schepenen van de Keure inzake verbintenissen van poorters bezaten t.o.v. hun medecontractanten uit de dorpen: dat werd de rechtbank van de indaginghe of dagvaarding door de luitenant-civil ${ }^{10}$.

Het principe waarop de rechtsmacht van de luitenant-civil berustte was eenvoudig en deed een beroep op bestaande overheidsstructuren: het gezag van de hoogste vorstelijke officier te Gent, de hoogbaljuw, werd uitgebreid en deze nieuwe attributie gedetacheerd naar een nieuwe officiehouder. De hoogbaljuw, die te Gent geen voorzitter was van de magistraat, bezat er wel samen met zijn substituut, de onderbaljuw - een belangrijke taak in de

9 O.P.B. IV, 275-277. Pl.v.Vl. II, 283-287.

10 Wij vermelden hier eens en voor goed de maatregelen betreffende de oprichting van de Gentse kamer van indaginghe en hun vindplaatsen.

Ordonnantie 14 februari 1541 (n.s.): O.P.B. IV, 275-277.

Decreet 13 mei 1541: O.P.B. IV, 300 ; Pl.v.Vl., II, 283-287.

Decreet 31 mei 1541: O.P.B. IV, 300-301.

Decreet 14 december 1541: O.P.B. IV, 342-343.

Ordonnantie 7 maart 1544 (n.s.): O.P.B. V, 12-13. Pl.v.Vl. II, 287-289.

Decreet 14 maart 1544 (n.s.): O.P.B. V, 14-15.

Decreet 2 juni 1544: O.P.B. V, 59-60.

Ordonnantie 9 december 1544: O.P.B. V,108-109. Pl.v.Vl. II, 290-291.

Decreet 9 november 1545: O.P.B. V, 191.

Decreet 14 november 1545: O.P.B. V, 192-195. 293.

Ordonnantie 8 maart 1552 (n.s.): O.P.B. VI, 227-228. Pl.v.Vl. II, 291-

Ordonnantie 25 februari 1557 (n.s.): O.P.B. VII, 159-164. Pl.v.Vl. II, 293-300.

Ordonnantie 6 april 1562: Pl.v.Vl. III, 198-201.

Verder zijn er vier wetteksten betreffende de oprichting van de rechtbank van de luitenant-civil van de indaginghe te Dendermonde:

Ordonnantie 4 mei 1544: O.P.B. V, 33-34. Pl. v. Vl. II, 300-302.

Ordonnantie 4 juni 1544: O.P.B. V, 60-63.

Decreet 2 januari 1546 (n.s.): O.P.B. V, 208-209.

Akte 25 februari 1546 (n.s.): O.P.B. V, 209. 


\section{P. LENDERS}

stedelijke rechtbanken, die boetstraffelijke zaken behandelden. Hij moest de vervolging instellen, de straffen requireren en de vonnissen uitvoeren. Door de ordonnantie van 14 februari 1541 werd een uitbreiding van bevoegdheid toegekend aan zijn ambt. Zij betrof burgerlijke aangelegenheden en werd onmiddellijk overgedragen aan een aparte officier. Deze werd in de ordonnantie omschreven als "Juge gheheeten lieutenant civil van onsen balliu van Ghent".

De rechtbank, die door deze man als plaatsvervanger van de hoogbaljuw werd voorgezeten, kreeg alleen bevoegdheid inzake verbintenissen zoals leningen, pachtcontracten, schulden, geschreven beloften van hulp of van bijdragen e.d. De oprichting ervan was een teken van welwillendheid voor de Gentse zakenlieden en corporaties: het maakte het de Gentse schuldeisers gemakkelijk bij het bekomen van hun recht en beknotte ten hunnen behoeve de bevoegdheid van de kleine plattelandsgerechten. Zo was trouwens ook het octrooi niet zo lang daarna verleend om de Sassevaart - het kanaal van Gent naar Sas van Gent - te graven en een verbinding met de Westerschelde te realiseren een teken dat de keizer de economische ontwikkeling van de Arteveldestad niet wilde afremmen.

\section{De Organisatie}

De voorzieningen voor een goede werking van een totaal nieuwe rechtbank waren talrijk en van uiteenlopende aard. Te Gent was de toestand na de zware repressie van keizer Karel in april 1540 nog steeds gespannen. Dat maakte het opstarten van een nieuwe instelling niet gemakkelijk: zij werd immers eerst als bestraffing en daarna pas als tegemoetkoming aangezien. Te Brussel was men er zich van bewust dat men heel wat kon leren van de werkwijze van het college van de Keure. Men wilde dan ook een vlot werkende en efficiënte rechtbank creëren, die de Gentse aanleggers geen reden tot het betreuren of het terugblikken naar vroegere verworvenheden zou geven.

Dat het nochtans niet allemaal van een leien dakje liep, wordt duidelijk uit het aantal wetgevende ordonnanties en uitvoeringsdecreten. Op 21 jaar tijd van 1541 tot 1562 - moest de regering 17 verordeningen uitvaardigen. Misschien zouden er nog meer opgemaakt geweest zijn, maar na het vertrek van Filips II naar Spanje werd de aandacht veel meer opgečist door de zorgwekkende religieuze ontwikkelingen en de weinig soepele politiek van kardinaal de Granvelle. Zo moest de vorstelijke overheid overgaan tot de oprichting van een zelfde rechtbank te Dendermonde om een vlotte rechtsbedeling te verzekeren. De Gentse zakenlieden verlangden zelfs nog meer dergelijke rechtbanken voor de realisatie van hun contracten, maar alle mooie beloften ten spijt werden die nooit opgericht. 


\section{DE LUITENANT-CIVIL VAN DE INDAGINGHE}

Een aantal van de betreffende overheidsmaatregelen werden in de verzameling van de Plakkaten van Vlaanderen opgenomen. Zij zijn veelal in het Nederlands gesteld. De Recueil des Ordonnances, die de regering van Karel V en Filips II bestrijkt, publiceerde er ook een aantal. Meermaals werden de daar afgedrukte akten in het Frans weergegeven, vooral wanneer ze reeds in het Nederlands in de plakkatenuitgave voorkwamen.

\section{Het Personeel}

De organisatie van de nieuwe rechtbank te Gent had oog voor een drietal belangrijke deelgebieden. De staf, zijn bezoldiging en de zetel van de nieuwe instelling maakten een eerste voorwerp uit van de vorstelijke belangstelling, de bevoegdheid en de procedures een tweede en de uitgebreidheid van het rechtsgebied een derde.

De voorzitter, luitenant-civil van de indaginghe geheten, vertegenwoordigde te Gent als vorstelijk officiehouder het soeverein gezag in de betwistingen, die hem werden voorgelegd. De vorst kon in zijn ambt zo maar niet ad nutum iemand benoemen. Vooreerst - en dat realiseerden zich de juristen van de Geheime Raad heel goed - sloeg het verbintenissenrecht op een ingewikkelde materie. Daarom moest men er steeds op toezien dat geroutineerde, universitair geschoolde juristen benoemd werden. Verder moest de benoemde een Vlaming zijn: dat wilde het ongeschreven recht. In 1620 benoemden de aartshertogen een Antwerpenaar Aurelius Augustus Malinaeus zonder rekening te houden met de grondwettelijke regels. Zij moesten hem na korte tijd naar de Raad van Brabant overplaatsen. In Vlaanderen was er ernstig verzet gerezen tegen deze aanstelling: men aanvaardde er immers geen Brabander in een overheidsambt ${ }^{11}$.

Ten slotte moest de luitenant-civil aan de persoonsvereisten voldoen, die aan elke rechter gesteld werden. Het decreet van 2 januari 1546 vroeg voor het bekleden van het officie van luitenant-civil te Dendermonde sens, prudence, litérature et expérience en fait de justice. De kandidaat moest daarenboven blijk geven van loyauté et bonne diligence. Het zelfde zal ook wel voor de functie te Gent gevraagd zijn, waar de eerste titularis Meester Adriaen de Pamele heette.

Het ambt van luitenant-civil stond in hoog aanzien. In 1620 verliet Charles Triest na de verwijdering van Malinaeus zijn zetel in de Raad van Vlaanderen om die van luitenant-civil te bezetten. En in 1706 werd Antoon Sersanders de Luna rechtstreeks van luitenant-civil tot voorzitter van de Raad van Vlaanderen bevorderd ${ }^{12}$. De advokaat J.A. Knobbaert kon dan ook op

11 Ph. VAN HILLE, o.c., 12.

12. J. BUNTINX, Inventaris van het Archief van de Raad van Vlaanderen, I (Brussel, 1964), 75-76 . 


\section{P. LENDERS}

het einde van een lange carrière getuigen dat de titularissen van de Indaginghe te Gent steeds voorname persoonlijkheden waren: "Minime itaque mirandum quod multi viri celebres et praeclari hoc munere fuerint functi" ${ }^{13}$.

Naast het ambt van voorzitter was er een plaats van griffier voorzien. Hij was met het schrijf- en registreerwerk belast. Antoon de Hille was de eerste van een lange reeks. In 1557 blijkt hij een bediende te hebben. De ordonnantie van 25 februari van dat jaar voorziet immers dat hij optreedt "gheassisteert met eenen clerck hem verstaende in het faict van practijcke". Er moet wel veel werk op de rechtbank geweest zijn.

De beide magistraten - luitenant-civil en griffier - kregen dezelfde fiscale exempties als de raadsheren van Vlaanderen. Zelfs de ceremoniěle preséance werd geregeld. Aan de voorzitter gaf de keizer rang na de onderbaljuw van de stad en aan de griffier na de griffiers van de Raad van Vlaanderen.

Voor het uitdragen van de dagvaardigingen op het platteland mocht de voorzitter een beroep doen op de boden van de Raad van Vlaanderen. De uitvoering van zijn vonnissen moest hij aanvankelijk toevertrouwen aan deurwaarders van de Raad. In 1547 kreeg hij de beschikking over twee eigen deurwaarders. In elk geval mochten de deurwaarders voor de uitvoering van hun soms moeilijke opdracht een beroep doen op plaatselijke gerechtsdienaars. De executoriale brieven van de luitenant-civil kregen dezelfde kracht als die van de Raad van Vlaanderen.

De rechtbank moest twee maal per week zitting houden. Aanvankelijk was daarvoor een grote zaal in het Gravensteen te Gent aangewezen, waarin op andere dagen het hoofdcollege van de Oudburg als rechtbank zetelde. Het Gravensteen was vooral bekend als het gebouw, waar het hoogste gerechtshof van het graafschap, de Raad van Vlaanderen, en het opperste leenhof, de Wetachtige Kamer, zetelden. De zaal leek echter na een korte inloopperiode niet ideaal voor de rechtbank van de indaginghe. Nog het jaar van de oprichting vroeg de pasbenoemde voorzitter om een rustiger lokaal. De ruimte waarin hij moest zetelen, werd nog al eens ingenomen door procureurs en advocaten van de Raad van Vlaanderen en door allerlei sollicitanten en volksmensen. De kastelein van het kasteel wilde hem alleen een andere zaal reserveren, indien de vorst het goed vond. Het decreet van 14 december 1541 ging op het verzoek in: het voorzag een kleine zittingzaal, een bureel en een kamer met een toonbank.

Overeenkomstig de wensen van de Gentenaars was de nieuwe rechtbank opgericht om "groote costen" te vermijden en "grootere schaede" te

13 J.A.KNOBBAERT, o.c., 466. Ofschoon aangaande het personeel van de rechtbank nog alles te doen is, vindt men toch - voor een eerste kennismaking namen van luitenanten-civil, griffiers en deurwaarders in J. BUNTINX, o.c., VIII, 355. Voor Dendermonde vindt men dezelfde naamgegevens Ibid., VIII, 165. 


\section{DE LUITENANT-CIVIL VAN DE INDAGINGHE}

voorkomen na de bestraffing van de Gentenaars. Haar werking mocht dus niet duur uitvallen en moest heel vlot zijn. Aanvankelijk lagen de werkingskosten erg laag. Zoals in het Ancien Régime gebruikelijk, werden alle personeelsleden ad casum betaald. Dit casueel inkomen steeg of daalde met het ritme van de behandelde zaken. Voor de vergoedingen van voorzitter en griffier was de voorziene mondelinge procedure een streep door de rekening. Met verloop van jaren werd die procedure echter meer en meer schriftelijk: consultaties, adviezen, tussenvonnissen, bezwaarschriften en andere omstandigheden brachten dit meer en meer mee.

Toch bleek de voorziene vergoeding te laag. Na circa drie jaar - op 14 maart 1544 - werd zij aangepast. In de ordonnantie kregen de deurwaarders het verwijt dat zij nog al eens te veel vroegen voor de uitvoering van hun opdrachten. Ook de luitenant-civil en zijn griffier werd dat aangewreven, maar in minder sterke termen. Het vragen van te hoge casuelen was een euvel, dat men in veel rechtbanken van voor de Franse Revolutie tegenkwam. Om verdere misbruiken te voorkomen werden de handelingen, waaraan een vergoeding verbonden was minutieus omschreven en getarifieerd. De vorst stipuleerde heel duidelijk dat hij wilde pourvoir au désordre qui cy apres d cause desdictz difficultez pourroit advenir et désirant éviter que ses subjectz ayans à faire desditz indaginghe ne soyent exactionnez oultre raison... ${ }^{14}$. Zo moesten de documenten van de griffier minstens 26 regels van 7 woorden tellen om voor een vergoeding van een vol blad in aanmerking te komen.

De ambten verbonden aan de rechtbank van de indaginghe werden zeker in de zeventiende eeuw - en wellicht reeds vroeger - aan het heersende regime van venaliteit der officies onderworpen. De resignatie van het ambt van luitenantcivil van Dendermonde in januari 1546 doet vermoeden dat er voor het aanstellen in die functie betaald was. Door de resignatieprocedure kon de bezitter van een officie zijn opvolger aanduiden en ontving hij een derde van de koopsom. De overblijvende twee derden gingen naar de benoemende overheid, die de transactie moest bekrachtigen en de nieuwe titularis goedkeuren. De wettiging van de resignatie vanwege de vorst werd in de Recueil des Ordonnances des Pays-Bas onder datum van 2 januari 1546 (n.s.) opgenomen ${ }^{15}$. In elk geval werd de functie van de laatste luitenant-civil te Gent voor de Jozefistische hervormingen duur verkocht. Pieter-Jozef van Hoorebeek telde er fl. 5670 voor neer en kreeg de voorkeur op de concurrerende kandidaat L.J. Bouvy, die fl. 600 meer bood, maar zo goed als

14 Decreet 14 maart 1544 (n. s.)

15 Zie over het procéde, dat officieel resignatio in favorem tertii heet: $\mathbf{P}$. LENDERS, De Ambtenaar en zijn Statuut op het Einde van het Ancien Régime. In Bijdragen tot de Geschiedenis, 67 (1984), vooral 80-89 . 


\section{P. LENDERS}

onbekend was aan raadsfiscaal J.F. Dierickx ${ }^{16}$, die betreffende de geschiktheid van de kandidaten geconsulteerd werd.

\section{Procedureregelingen}

De procedureregelingen waren een technische aangelegenheid. Zij boeiden weinig mensen, wellicht alleen enkele juristen en procureurs, maar waren onontbeerlijk om een vlot en eerlijk functioneren van de rechtspleging te waarborgen. Meester Jan de Blasere, opvolger van de eerste titularis van de rechtbank der indaginghe, had er tijdens zijn inrijperiode werk van gemaakt alles op te tekenen wat voor verbeteringen vatbaar was. Hij had een lange lijst van richtlijnen en verbodsbepalingen opgemaakt, die hem nodig leken om de rechtbank een vlotte werking te verzekeren. Zij bevatte 47 artikels, in het geleerde jargon van de tijd opgesteld en nu zelfs voor rechtshistorici niet altijd onmiddellijk duidelijk. Zij betroffen zo wel het instellen van een geding als het verloop van de gerechtszitting en de uitvoering van de vonnissen en beoogden vooral het uitschakelen van veel voorkomende misbruiken ${ }^{17}$.

Een van de primaire bekommernissen van de Blasere - en wellicht van de hele Gentse zakenwereld - was het vlugge verwerken van klachten, eisen en betwistingen inzake verbintenissen. Daarom verlangde hij dat men niet meer dan acht dagen uitstel zou verlenen na de dagvaardingsdatum en dat de betrokken procureur of pleitbezorger zou aanwezig zijn. Hij alleen zou het risico van de afwezigheid dragen. Een ander artikel regelde procedurieel het verstek van een der partijen. De aanlegger moest zijn eisen duidelijk formuleren en meteen het hele dossier voorleggen. Anderzijds mochten de deurwaarders niet tot de uitvoering van de vonnissen overgaan zonder van de rechtbank een schriftelijke opdracht gekregen te hebben.

Een delikaat punt lijkt de goede trouw en de eerlijkheid van partijen en procureurs geweest te zijn bij hun verschijnen en optreden voor de rechtbank. De procureurs moesten zich goed op de hoogte stellen van alle aspecten van de zaak, die zij verdedigden. Zij moesten de betwisting ernstig onderzoeken en de oorsprong van de eis of van de schuld vermelden. Zij mochten geen steekpenningen van de tegenpartij aannemen en moesten desgevallend van hun basisdocumenten inzage geven aan de verweerder. Op straffe van boete mochten zij zonder gegronde redenen niet de onbevoegdheid van de rechtbank ter verweer opwerpen. Zij moesten door de voorzitter aanvaard worden en mochten geen documenten achterhouden en die pas op het einde voorleggen om te mogen tripliceren. Zo'n derde tegensprakelijke confrontatie was in deze

16 Raad van Financiën (Algemeen Rijksarchief te Brussel) 3915: Decreet 1 september 1768. Geheime Raad 468: benoeming van Hoorebeek.

17 Ordonnantie 4 juni 1544. 


\section{DE LUITENANT-CIVIL VAN DE INDAGINGHE}

rechtbank uitgesloten: zij wilde immers een snel werkende instantie zijn. Verder werd het na een minnelijke schikking onmogelijk gemaakt een nieuw proces in te spannen om de kosten van het voorafgaandelijke procederen te verhalen: die werden voortaan geacht in de overeenkomst ingebouwd te zijn.

Een laatste groep maatregelen betrof de uitvoering van de vonnissen. $\mathrm{Zij}$ handelden over het opstellen van de tekst en het registreren ervan door de griffier. Verder kwamen de beledigingen na de uitspraak en tijdens de debatten ter sprake. Het pandnemen en het beslagleggen werden geregeld. Aan de deurwaardersexploten en de dwangbevelen werd veel aandacht besteed. Wij vermeldden reeds dat de deurwaarders maar betalingsbevelen mochten uitvoeren na schriftelijke opdracht van de rechter. Bij een gerechtelijke verkoop was het hun alleen toegelaten vee onder de hamer te brengen, indien alle andere "kateilen" (roerende goederen) verkocht waren en de opbrengst onvoldoende bleek. Met de inning van de boeten moest de ontvanger van de exploten van de Raad van Vlaanderen belast worden.

Tegen de vonnissen van de luitenant-civil was geen beroep in de strikte zin mogelijk d.i. met opschorting van het vonnis. Wel was er "reformatie" voorzien door de Raad van Vlaanderen. Deze procedure, die men alleen in Vlaanderen aantrof, schortte de uitvoering van het vonnis niet op, maar bood toch mogelijkheid tot verbreken ervan door een arrest. Deze rechtspraktijk werkte afschrikwekkend en kon ernstige problemen meebrengen in verband met de geleden schade, indien de Raad van Vlaanderen het vonnis verbrak. Daarom werd alleen een pandgeving toegepast. De vorstelijke ordonnantie van 4 juni 1544 drukte het zo uit: "Des sentences, qui se rendront par ledit lieutenant civil n'y aura appel; ainsi seulement seront réformables au Conseil de Flandres" 18.

De procedurevoorschriften gaven blijk van ontwikkelde gerechtelijke gewoonten. De grote werken van Philip Wielant voor burgerlijke en boetstraffelijke procesvoering in het begin van de zestiende eeuw tonen trouwens aan dat Vlaanderen een grote ontwikkeling kende inzake rechtspleging. Het blijkt hier dat het niet alleen om theorie ging, maar dat die ook in de praktijk werd omgezet.

\section{Het Rechtsgebied}

Zo de technische regeling van de gerechtelijke actie weinig interesse verwekte, waren de vragen en betwistingen betreffende de uitgebreidheid van het territoriale bevoegdheidsgebied erg talrijk en met veel aandrang gedaan. De stelling van V. Fris moet in dit verband genuanceerd worden. Hij vond dat er gewoon een overdracht van gezag geweest was van de Gentse magistraat naar de luitenant-civil: "Son autorité sur le Vieux Bourg et les villes et

18 - Zie over de "reformatie": J. BUNTINX, o.c., VI, 6. 


\section{P. LENDERS}

chatellenies de Courtrai et de la Flandre orientale lui est définitivement enlevée et attribuée au luitenant civil" 19.

De ordonnantie van 14 februari 1541 had het gebied, dat vroeger onder de Gentse magistraat ressorteerde en dat werd overgedragen aan de luitenant-civil, erg ingeperkt. Het grootste gedeelte ervan was naar zijn natuurlijke rechter verwezen en niet meer aan de nieuw gecreäerde gerechtsinstantie onderworpen. De stichtingsakte had slechts 68 dorpen als territoriale basis voor de "indaginghen" weerhouden, veelal gelegen binnen de grenzen van de Oudburg en minder dan drie mijl (circa $17 \mathrm{~km}$.) van de stad verwijderd. Een maand later herinnerde de ordonnantie van 7 maart 1541 er nog eens voor alle duidelijkheid aan dat het alleen ging om "débiteurs demourans au plat pays ès paroiches et limites cy-dessuz désignez dextendue de trois lieues et en dessoubz et a lenviron de nostre dicte ville de Gand".

De Gentse zakenwereld had er erg ontgoocheld op gereageerd en aangedrongen op de uitbreiding van het gerechtelijk territorium tot aan de grenzen van het oude kwartier van Gent. $\mathrm{Zij}$ vonden de nieuwe regeling erg nadelig: "d cause de quoi leur a convenu et convient procéder contre leurs dictz débteurs ès lieu de leur demeure da grandz coustz, frayz et despens" 20 . Hun vraag was duidelijk: "amplier et extendre lesdictes indaginghes et si loings que les dictz suppliants en soullaient user auparavant". En als het ware om alle misverstand uit te sluiten hadden de Gentenaars eraan toegevoegd "que de notre présente grace, ottroye et concession, aux conditions et en la manière dicte, ils faicent, seuffrent et laissent lesdictz de nostre ville de Gand plainement et paisiblement joyr et user, sans leur faire, mettre ou donner, ne souffrir estre faict, mis ou donne aulcun trouble ou empeschement au contraire" 21 .

Samen met de Gentse magistraat hadden de zakenlieden ook het intrekken van het artikel 59 van de Carolijnse Concessie gevraagd, althans voor de toegang tot de rechtbank van de indaginghe. Dit had aan de buitenpoorters, die zo wat overal in Vlaanderen woonden, de privileges van de Gentse burgers ontnomen. Nu had een groot aantal mensen juist dit statuut aangevraagd omwille van de voordelen van het recht van indaginghe.

Maar ook het platteland had zich niet onbetuigd gelaten. Het had al bij voorbaat positie ingenomen tegen een verder herstel van de Gentse machtspositie. Zo groot was de vrees daarvoor dat een aantal rijkere landslieden meteen al getracht hadden zich aan de jurisdictie van de nieuwe

19 V.FRIS, o.c., 182.

20 Zij voegden er zeer vriendelijk bij "Les très nobles prédécesseurs de Vostre Majesté leur eussent accordé certain privilege, appelle en thiois l'indaginghe....": ordonnantie 7 maart 1544 (n.s.). Cf. Decreet 14 november 1545.

21 Ordonnantie 7 maart 1544 (n.s.). 


\section{DE LUITENANT-CIVIL VAN DE INDAGINGHE}

rechtbank te onttrekken. Zij vroegen bij een dagvaarding aan de besturen van nabije steden als Aalst, Dendermonde, Geraardsbergen, Kortrijk en Oudenaarde een attest, dat bevestigde dat zij hun poorter waren. Daarmee hadden zij alle oproepen van de luitenant-civil afgewezen ${ }^{22}$.

De ordonnantie van 7 maart 1544 bracht een antwoord op een dubbele bekommernis. Het veroordeelde het dubieuze procédé van de valse attesten. Het ging verder ten dele in op het verzoek van de Gentenaars. Het schonk aan de luitenant-civil weliswaar niet het hele gebied van het vroegere kwartier van Gent als gerechtsterritorium terug; het breidde dit landschap wel uit door de inlijving van 86 dorpen, veelal in het Land van Aalst en de Kasselrij van Oudenaarde gelegen. De vorst verruimde het bevoegdheidsgebied principieel door de drie-mijlsstraal te vervangen door een vier-mijlsstraal. In de kwestie van de buitenpoorters kwam geen klaarheid: klaarblijkelijk vond men te Brussel de regeling van artikel 59 van de Carolijnse Concessie duidelijk genoeg en verlangde men geen verandering.

Zowel Gent als het platteland reageerden onmiddellijk op de nieuwe beslissing. De stad drong aan op een verdere verruiming van het bevoegdheidsgebied. Uit de plattelandsomschrijvingen was het Vrije van Brugge, een der vier Leden van Vlaanderen, er het eerste bij om te protesteren: de ordonnantie van 7 maart 1544 schond zijn privileges en rechten. Wellicht onbewust had de Geheime Raad een gehucht van het Vrije aan de luitenantcivil onderworpen. Dat heette beroving van de inwoners van hun natuurlijke rechter! Het verzet betrof het dorp Ursel. Dit ressorteerde ten dele onder het Brugse Vrije (Ursel-'t Vrije) en ten dele onder de Oudburg van Gent (Ursel -'t Gentse). Het hoofdcollege bekwam heel vlug rechtsherstel: alleen de bewoners van Ursel-'t Gentse werden duidelijkheidshalve op 2 juni 1544 aan de rechtbank van de luitenant-civil onderhorig gemaakt.

Heel wat dorpsbaljuws en plaatselijke overheidspersonen volgden de richting, die door het Vrije aangegeven was en opperden juridische bezwaren tegen hun afhankelijkheid van een Gentse dagvaarding. De ordonnantie, die het bevoegdheidsterritorium omschreef en daaronder nominatim 86 nieuwe dorpen onderbracht, had in een slotclausule vermeld dat al die dorpen in een straal van vier mijl rond de stad Gent moesten gelegen zijn: "pourvu que nulle desdictes paroiches ne soit distante de nostredicte ville de Gand plus de

22 "Mais en ce faisant treuvent que iceulx debteurs, après plusieurs délayz et subterfuge se dyent bourgeois de noz villes d'Alost, de Grandmont, d'Audenarde, de Tenremonde, Courtray ou d'aultres villes voisines et en vertu des lettres closes quilz obtiennent des gens de loy de leur prétendue bourgeoisie font cloire la voye de justice aux loix de leurs demeures. Tellement que ceulx de nostredite ville de Gand sont contrains daller procéder de nouveau è lieux ou villes de leur prétendue bourgeoisie a leur très grand grief, dommaige et intérest": Ordonnantie 7 maart 1544. Aan de klacht wordt opnieuw aandacht besteed in het decreet van 14 november 1545 . 


\section{P. LENDERS}

quatre lieues selon commune estimation, interdisant et défendant ausdictz de Gand de user desdictes indaginghes èsdictes paroiches scituées plus loing dicelle ville que quatre lieues, a peine de perdre leffect de cestes" 23 . Nu waren er dorpen of buurtschappen, die buiten deze straal lagen en toch in de lijst opgenomen waren. Even gretig om hun onderhorigheid af te wijzen waren de plaatselijke besturen, die wel binnen de vier-mijl-straal gelegen, maar niet met name vernoemd waren. De afkeer en vrees voor de Gentse dominantie en de zucht naar autonomie moeten wel heel sterk geweest zijn.

Die protestbewegingen dwongen de vorst al vlug tot een duidelijke stellingname. Op 9 december 1544 besliste hij dat alle reeds vermelde dorpen onder de jurisdictie van de Gentse kamer van indaginghe bleven ressorteren, ook indien zij meer dan vier mijl van de stad verwijderd lagen. Hij hief daarom die grens op. Verder kwam er echter geen concentratie op Gent. Na een half jaar aarzelen, op 4 juni 1545, werd er wel een gelijkaardige rechtbank te Dendermonde opgericht: daar konden de Gentse poorters terecht met hun eisen inzake niet nagekomen verplichtingen. Wij komen er verder op terug.

Daar de nieuw opgerichte rechtbank van Dendermonde alleen in het oostelijk gebied van Vlaanderen rechtsmacht bezat en het platteland, dat zuidelijk van Gent lag, economisch en financieel heel wat belangrijker was voor de stad, drong men opnieuw aan om de oude toestand te herstellen, zij het dan ten voordele van een vorstelijk rechter. Op 5 november 1545 werd het verzoek principieel afgewezen. Wel werd er door de Geheime Raad bij deze globale afwijzing een opening gelaten: de stad mocht eventueel de lijst van de dorpen aangeven, die vroeger onder haar jurisdictie vielen.

De stadsmagistraat ging onmiddellijk op deze suggestie in en stelde zonder dralen de nodige documenten op. Hij liet niet alleen éen lijst maar drie lijsten opmaken en aan de Geheime Raad presenteren.

De eerste lijst somde de dorpen op, die "jeghenwordelic indaginghe an deselve Majesteyt begheeren". $\mathrm{Zij}$ waren met 132 en gaven de voorkeur aan de eenvormige rechtspraak van een vorstelijke rechtbank in de Vlaamse hoofdstad. Men vindt in die lijst merkwaardig genoeg een groot aantal gemeenten uit het Kortrijkse als Waregem, Izegem, Harelbeke, Kuurne, Vichte, Zwevegem.

Op de tweede plaats bracht het Gentse document de lange lijst van de lokaliteiten, die weleer het kwartier van Gent uitmaakten. $\mathrm{Zij}$ werden in kringen van mijlzones gerangschikt, van vier tot zeven mijl ( 23 tot $40 \mathrm{~km}$.). Men telt er respectieflijk 13, 37, 32 en 70 dorpen of gehuchten: sommigen waren reeds dagvaardbaar, anderen niet.

De derde lijst bracht de reeks "parochies", die niet dagvaardbaar waren en die terug aan de jurisdictie van een te Gent zetelende rechter konden onderworpen worden. Men telt er 133. 


\section{DE LUITENANT-CIVIL VAN DE INDAGINGHE}

Vijf dagen na de eerste afwijzing werd ook het tweede verzoek volledig verworpen. Wel werd in de apostille van 14 november 1545 de belofte gedaan elders rechtbanken van indaginghe onder leiding van een luitenant-civil op te richten, parallel met die van Dendermonde: On ne treuve raisonnable dextendre siavant lindaginghe et seroit par trop grande charge pour les povres gens de les attraire en toutes petites causes si loing hors de leur domicile. Mais pour soullaiger les supplians et les bourgeois de Gand, lon trouveroit convenable de mectre aucuns lieutenans en aultres lieux pardevant lesquels les bourgeois pourroient attraire leurs debteurs comme on a faict d Tenremonde. 24

Toen de nieuwe rechtbanken er niet kwamen, gingen de Gentenaars opnieuw ten aanval over. Koppig drongen zij opnieuw aan op het herstel van hun oude gezagszone. Die omvatte - zo specificeerden zijn zelf - met uitzondering van de besloten steden de kasselrijen van de Oudburg, van Oudenaarde en van Kortrijk en die van het Land van Waas, van Dendermonde en van Aalst. Zij strekte zich verder benoorden de Arteveldestad uit over de Vier Ambachten (Axel, Assenede, Boekhoute en Hulst).

De moeilijke tijdsomstandigheden brachten mee, zo argumenteerden de Gentse verzoekschriften, dat er veel slechte betalers waren en dat maakte het opzoeken van de plaatselijke rechters erg tijdrovend. Tot overmaat van ramp waren de burgerlijke gedingen in de regio van de Vier Ambachten gebonden aan trimestriële zittingsperioden van de rechtbanken, "Havegedinghen" geheten, en dat was bijzonder hinderlijk voor het zakenleven.

Het feit dat de buitenbevolking zich in de stad moest komen verantwoorden voor niet nagekomen verplichtingen woog minder zwaar - zo voorkwamen de Gentenaars een opwerping van de Geheime Raad - dan het onderbreken van de continue handelsstroom met het platteland.

In het voorjaar van 1562 vond het Gentse aandringen uiteindelijk gehoor. Op 6 april 1562 werden 72 verdere dorpen en gehuchten bij het rechtsgebied van de Gentse indaginghe ingelijfd. In Oost-Vlaanderen liep nu de grenslijn tot Zarlardinge, Hemelveerdigem, Sint-Maartens-Lierde en in WestVlaanderen tot Waregem en Desselgem. Volgens het getuigenis van een latere ordonnantie van 4 februari 1612 had men daarmee een zesmijlszone willen uitbouwen.

$\mathrm{Na}$ deze territoriale afbakeningen was er nog een vraag die om antwoord of verduidelijking vroeg: aan de buitenpoorters dezelfde toegang tot de rechtbank van de indaginghe verschaffen als aan de echte poorters. Met verloop van tijd was het verzoek voor gelijkberechtiging verwikkeld geraakt in een nieuwe juridische spitsvondigheid. Vooral buitenpoorters, - maar daarna ook gewone

24 Verzoekschrift met apostille-decreet 14 november 1545 . Van de 132 dorpen, die onder de Gentse luitenant-civil verlangden te ressorteren, waren er 50 op meer dan zes mijl afstand van Gent gelegen. 


\section{P. LENDERS}

landslieden, - droegen meer dan eens hun rechten over aan een volberechtigde poorter, opdat deze voor hen voor de snelle en efficiënte rechtbank van de luitenant-civil zou procederen. Was dit toelaatbaar of was het een omzeilen van de wet?

Het antwoord op de beide vragen viel op 8 maart 1552. De vorstelijke beslissing verwees de buitenpoorters met hun eisen naar de rechtbanken van de verweerders, zoals het algemeen rechtsgebruik wilde. Eén uitzondering werd hierop gemaakt voor de buitenpoorters, die een geding inspanden, maar zelf binnen het jurisdictiegebied van de luitenant-civil woonden: zij kregen wel toegang tot de Gentse vorstelijke instantie. De ordonnantie bracht daarmee een verzachting van het bestraffende artikel 59 van de Carolijnse Concessie, dat de buitenpoorters alle poortersrechten ontnam. Maar verder wees de vorst alle fictieve overdrachten van vreemden aan poorters af: afspraken van die aard gaven geen recht op een behandeling door de vorstelijke rechtbank van de luitenant-civil.

Door al deze maatregelen waren zowel de bevoegdheidszone van de Gentse luitenant-civil van de indaginghe vastgelegd als de vereiste qualificaties van de eisers en verweerders om toegang te krijgen. De volgende decennia zou het land - en niet het minst de stad Gent - een zware crisis doormaken ten gevolge van de godsdiensttroebelen. Tot aan de regering van de aartshertogen bleef alles bij het oude. Door een resolutie van de Staten-Generaal der Nederlanden kregen de Gentenaars in oktober 1577 de privileges terug, die hun in 1540 ontnomen waren met éen beperking "moyennant qu'ils ne soyent prejudiciables aux aultres provinces, villes ou chastellenies" 25 . De rechtbank van de luitenant-civil bleef verder functioneren onder het gezag van de vorst en kwam niet terug in de handen van het college van de Keure: dat werd niet door de kasselrijen aanvaard.

\section{DE VORSTELIJKE RECHTBANK VAN DE INDAGINGHE TE DENDERMONDE}

De oprichting van een vorstelijke rechtbank voor geschillen inzake verbintenissen te Dendermonde bracht een hulpinstelling tot leven, die de vernietiging van de jurisdictie van het Gentse college van de Keure over het platteland moest opvullen en hulp bieden aan de economische ontwikkeling van de keizerlijke geboortestad. Tevens wilde zij de verweerders - ruimtelijk gezien - dichter bij de rechtbank brengen.

25 L.P. GACHARD, Notice historique et descriptive des archives de la ville de Gand (Extrait des mémoires de l'Académie royale de Belgigue, XXVII, 1852) 16. 


\section{DE LUITENANT-CIVIL VAN DE INDAGINGHE}

Dendermonde was in de jaren voor de crisis van 1540 een rustige stad gebleven: zij had niet mee gedaan aan de roerige emancipatie-activiteiten van andere Vlaamse steden. Daar werd zij nu voor beloond.

Op 4 mei 1544 werd in de stad een rechtbank opgericht zoals te Gent en onder het voorzitterschap van een eigen luitenant-civil gesteld ${ }^{26}$. Het initiatief van de vorst sproot voort uit een dubbele bekommernis: vooreerst voorkomen dat de Gentenaars moesten "procederen voor de sulbalterne jugen vanden voorseyden dorpen" 27 en verder ook "opdat henlieden corte expeditie van rechte behoorelijcke geadministreert sy". De geboortestad van de keizer mocht in geen geval door de slechte werking van de rechtbanken van het platteland gehinderd worden. De dagvaarding te Dendermonde werd voorbehouden aan de Gentse poorters. Toch mochten ook de burgers van Dendermonde er met hun klachten over de uitvoering van verbintenissen procederen.

Als jurisdictionele zone werden 74 steden, dorpen en gehuchten opgesomd, waaronder Sint-Niklaas, Lokeren en Ninove, maar ook bijzonder veel kleine, nauwelijks bekende gehuchten als Puverbeke, Paddeschoot en Aarschot (alle drie onder Sint-Niklaas gelegen), Zwijveke (Sint-Gillis-bijDendermonde) e.a., zodat deze lijst minder indrukwekkend is dan de lijsten met de dorpen, die aan Gent voorbehouden waren. De nieuwe rechtbank mocht geen inbreuk plegen op de rechtsmacht van de plaatselijke magistraat, ook niet zo die in bepaalde gevallen gezag bezat over de dorpen van het Land van Dendermonde. Wel werd uitdrukkelijk gestipuleerd dat het buitenpoorterschap van andere steden geen beletsel vormde om gedagvaard te worden, zo de bezitters van dit poorterschap in het beschreven rechtsgebied woonden.

Een maand na de oprichting, op 5 juni 1544, volgde een ordonnantie met procedureregelingen en voorschriften. De wet maakte duidelijk dat het de bedoeling van de vorst was het Land van Waas, van Dendermonde en van Bornem als territorium aan de pas opgerichte rechtbank te geven. Zij kreeg een eigen griffier, maar moest voor het uitdragen van de dagvaardingen een beroep doen op de stedelijke messagiers. Opnieuw werd een snelle afwerking der behandelde klachten bevolen, zoals te Gent reeds gebruikelijk was. Evenmin als de collega van de Arteveldestad was het de Dendermondse luitenant-civil toegelaten een vue de lieu te doen; het ging immers om verbintenissen en niet om waarde-schattingen. Zo de luitenant-civil dit toch

26 Betreffende de wetsregelingen noot (10).

27 Dit thema komt herhaaldelijk terug in de officiele documenten. Zo schrijven de aartshertogen in hun ordonnantie van 4 februari 1612: "Lesquels ne font si prompte expédition, ny si peu couteuse aux parties, que les officiers de $l^{\prime}$ Indaginghe". In Pl. v. Vl. III, 201. 


\section{P. LENDERS}

deed, mocht hij daarvoor niet vergoed worden. Verder regelde de ordonnantie in de detail de procedures bij afwezigheid van de gedaagde.

\section{VERDERE ONTWIKKELING DER BEIDE RECHTBANKEN NA 1585}

$\mathrm{Na}$ het herstel van de rust in de Zuidelijke Nederlanden hebben de beide rechtbanken van de Indaginghe rustig verder gewerkt. Parallelle gerechtelijke instanties werden niet meer opgericht. De aandacht ging vooral naar de uitbreiding van het rechtsgebied en de aanpassing van de gerechtskosten aan de stijgende levensduurte, die het gevolg was van de prijsrevolutie der zestiende eeuw.

De werking van de beide rechtbanken had na een halve eeuw orde gebracht in de wereld van contracten en pachten. Men had met verloop van jaren geleerd wat voor de geldigheid ervan nodig was om als volwaardige verbintenis door de rechtbank erkend te worden. Dat bleek zo'n belangrijke verworvenheid te zijn dat de Gentse contracterende partijen meer en meer in de verbintenissen de clausule inlasten dat bij betwisting alleen de Gentse luitenant-civil bevoegd was om over de naleving uitspraak te doen. In feite werd daarmee het territorium van de rechtbank steeds meer uitgebreid. Dit leidde tot moeilijkheden. In 1612 moesten de aartshertogen regulerend in deze zaak tussenkomen. Zij bepaalden dat de clausule alleen geldig was, zo de contractspartner niet buiten een zesmijlzone ( $35 \mathrm{~km}$.) van Gent verwijderd leefde ${ }^{28}$.

Niet alle instanties waren gelukkig met deze beschikking. Het gebeurde dan ook wel eens dat een plaatselijke overheid ertegen op kwam. Zo verzette de provoost van de heerlijkheid van het Gentse Sint-Pieters zich in de jaren zeventig van de achttiende eeuw zo heftig tegen de dagvaarding van een van de inwoners dat twee vorstelijke tussenkomsten nodig waren om hem tot de aanvaarding van de rechtsmacht van de luitenant-civil te brengen. Zo wel Maria-Theresia in 1779 als Jozef II in 1785 herhaalden dat bij opname in het contract van de clausule van dagvaarding door de luitenant-civil alleen de zesmijl-zone gold ${ }^{29}$.

Betwistingen over het bevoegdheidsgebied deden zich ook voor tussen de twee collega's-rechters te Gent en te Dendermonde. Een Gents verzoekschrift van 14 november 1544 had reeds de aandacht getrokken op het feit dat door

28 Ordonnantie 12 februari 1612 in $P$ l. v. Vl. III, 201. Er werd heel duidelijk gesteld dat het alleen ging om "personnes qui par contract se sont soumises à la jurisdiction dudit lieutenant civil" of "qui par les contracts en question ont expressément advoué la jurisdiction dudit suppliant"

29 O.P.B.A., (3e série) XI, 376-377 en XII, 439. 


\section{DE LUITENANT-CIVIL VAN DE INDAGINGHE}

een beschikking van de vorst een aantal dorpen tot het rechtsgebied van de beide rechtbanken behoorden. Het werd een touwtrekken tussen de twee collega's wie wat tot zijn jurisdictionele zone mocht rekenen. Een oplossing werd pas na een eeuw gebracht. Het was de enige waardevolle landvoogd in de zeventiende eeuw tussen de aartshertogen en de Beierse keurvorst MaxEmmanuel, de Duitse aartshertog Leopold-Willem van Oostenrijk (16471656), die daarvoor zorgde.

De eerste maatregel werd op initiatief van de regering genomen. Het decreet van 1 december 1653 verbood de luitenant-civil van Dendermonde nog dagvaardingen uit te schrijven voor inwoners van Wetteren en een vijftal dorpen uit de omgeving 30 .

De tweede regeling kwam er waarschijnlijk op voorstel van de luitenantcivil van Dendermonde Jean-Baptiste de Roy, kamerheer van de landvoogd. Hij poogde de hangende problemen door onderlinge afspraak te regelen. Zijn Gentse collega-rechter Jacques-Philippe Van der Beken, die wellicht onder druk gezet was, wilde niet zelf aan de onderhandelingstafel gaan aanzitten. Hij vaardigde daartoe de pensionaris van Doornik af, Louis d'Errembault (1625-1695), de later omstreden voorzitter van de Raad van Vlaanderen ${ }^{31}$. Een eerste overeenkomst van 15 december 1655 kon zijn instemming niet wegdragen. Twee maanden later, op 19 februari 1656, kwam een nieuw akkoord tot stand over de jurisdictiezones van de beide rechtbanken. Nu aanvaardde de Gentse luitenant-civil het wel. Voor alle zekerheid liet men de overeenkomst door de landvoogd bekrachtigen: dat werd de inhoud van het decreet van 24 maart 1656. De afspraak voorzag dat de inwoners van Lokeren, Eksaarde (fusiegemeente Lokeren) en Moerbeke-Waas voortaan alleen te Gent dagvaardbaar waren en dat de Dendermondse kamer van de indaginghe Erembodegem (fusiegemeente Aalst), Lede en Wichelen tot zijn rechtsgebied mocht rekenen ${ }^{32}$.

Niet alleen de rechters kibbelden om hun rechtsgebied, ook de deurwaarders bestreden elkaar. Hier kwam de echte reden van het conflict duidelijker op de voorgrond: het persoonlijke financiële voordeel. In het Gentse betrof de onenigheid de activiteit van de deurwaarders van de Raad van Vlaanderen. Klachten over het optreden van de deurwaarders van de luitenantcivil werden naar de Raad van Vlaanderen gedraineerd, zodat de deurwaarders van de Raad mochten optreden. Uiteindelijk werd op 24 december 1653 te Brussel beslist dat klachten over het optreden van de deurwaarders van de indaginghe alleen tot de luitenant-civil mochten gericht worden ${ }^{33}$.

\footnotetext{
$30 \quad$ Pl.v.Vl. III, 202-203.

31 Zie E. DE BORCHGRAVE in Biographie nationale, VI (Brussel, 1878)

32 Pl. v. Vl. III, 203-205.

33 Pl. v. Vl. III, 203.
} 685-693. 


\section{P. LENDERS}

De boden van de Raad van Vlaanderen, die belast werden met het uitdragen van de dagvaardingen van de luitenant-civil, vonden reeds op het einde van de zestiende eeuw dat zij onvoldoende vergoed werden. De klacht hield wellicht verband met de stijgende prijzen. Van af 1586 hadden zij van de vorst de toelating bekomen om gedurende zes jaar een tariefverhoging toe te passen. Naderhand was deze toelating regelmatig verlengd. Na veertig jaar bekwamen zij dat de voorlopige tarifering definitief werd. Een bijkomende reden voor de verhoging was - naast de inflatie - het feit dat streken benoorden Gent regelmatig door Hollandse troepen onveilig gemaakt werden als contributiegebied d.i. landstreek waar de vijand regelmatig onder allerlei bedreigingen opeisingen deed ${ }^{34}$. Zo kon deze verhoging tevens als "bibbergeld" of vergoeding voor werk in gevaarlijke zones aangezien worden 35 .

In het algemeen heeft men de indruk dat de rechtbank van Dendermonde het minder druk had dan die van Gent. Bepaalde delen van het Waasland en van het Land van Dendermonde waren meer op Antwerpen georiënteerd dan op Gent. Wellicht is de vroege resignatie van de eerste luitenant-civil van Dendermonde Jacques de Schoonhove na anderhalf jaar zetelen een teken van het beperkte werk en het lagere inkomen.

Uit de mooie inventaris van J. Buntinx van de archieven van de Raad van Vlaanderen blijkt dat door de Raad vier maal meer zaken in reformatieberoep werden behandeld tegen vonnissen van Gent dan tegen vonnissen van Dendermonde. De respectieve cijfers 75 en 19 geven wellicht een beeld van de relatieve belangrijkheid en activiteit van de beide rechtbanken.

Alles goed en wel beschouwd werd er eigenlijk weinig verzet aangetekend tegen de uitspraken van de Gentse luitenant-civil. Dit heeft ten dele te maken met de keurigheid van de procedures en van de uitspraken en met de vorm van het beroep, de reformatie, maar voorzeker ook met de veel opgenomen clausules dat bij betwisting over de uitvoering van het contract alleen de luitenant-civil van Gent bevoegd was. Dit verzekerde niet alleen een vlugge beslissing, het sloot ook de kosten van een beroep uit en verruimde het bevoegdheidsgebied tot zes mijl, ook ten nadele van Dendermonde. Op die manier won Gent een deel van het invloedsgebied terug dat haar in 1540 ontnomen was.

34. Zie over de contributielanden in oorlogstijd H. VAN HOUTTE, Les occupations étrangères en Belgique sous l'Ancien Régime. I (Gent, 1930) 144 156.

35 Decreet 27 juli 1626 in Pl. v. Vl. III, 205-206. 


\section{DE LUITENANT-CIVIL VAN DE INDAGINGHE}

\section{BESLUIT}

Het traditionele beeld van de Kamer van Indaginghe onder leiding van de luitenant-civil, zoals het in De Rijksarchieven in de Provinciën voorkomt, is aan herziening toe. Er was er meer dan énn: drie jaar na die van Gent werd die van Dendermonde opgericht in 1544. Nog andere werden beloofd, maar kwamen nooit tot stand.

Deze rechtbanken hoorden tot de kategorie der tribunaux particuliers, zoals P. de Neny het formuleerde. Die werden geleid door juges délegués ${ }^{36}$. De ordonnantie van 9 december 1544 stelde duidelijk dat de luitenant-civil een afgevaardigd of gecommitteerd rechter was: "by Ons gecommitteert op de indaginghe derselve stede", heette het. Vór 1540 had de stad Gent zelf die rechtsmacht bezeten. In de strijd van de vorst tegen haar suprematie had die haar dat overwicht en gezag ontnomen en door de benoeming van een rechter op twee plaatsen zelf de jurisdictie uitgeoefend.

De rechtshistoricus E. Defacqz plaatste de instelling van de luitenantencivil bij de uitzonderingsrechtbanken, die hij enerzijds zag functioneren naast "natuurlijke en gewone rechters" maar verder omschreef als "tout régime, qui n'a pas pour base l'exacte égalité des membres d'une même nation, tout systeme, qui établit soit pour les personnes, soit pour les choses une règle, qui n'est pas la loi commune" 37.

De oprichting van de vorstelijke kamers van de indaginghe is wel eens de meest efficiënte maatregel van bestraffing voor Gent geheten ${ }^{38}$. Toch is de stad ze niet steeds zo blijven zien. In de loop van de jaren heeft zij haar oordeel herzien en is zij de werking van de rechtbanken van de luitenant-civil - vooral die van Gent - niet meer als een beknotting van haar rechtsmacht, maar als een voorrecht en een beveiliging gaan zien. Die veranderde houding komt o.m. duidelijk tot uiting in de capitulatie van de stad na de slag bij Ramillies (1706), die het Anjoubewind verdreef. Bij zijn overgave aan het Anglo-Bataafse opperbevel vroeg Gent uitdrukkelijk de instelling van de luitenant-civil te mogen bewaren. Ook bij de tweede capitulatie op 1 januari $1709 \mathrm{kwam}$ het behoud van de rechtbank op haar lijst van privileges voor ${ }^{39}$.

Te Brussel wist men zeer goed dat de stad erg gebrand was op het bezit van de instelling. Na de verrassingsinname en bezetting van de stad door de

36 P. DE NENY, Mémoires historiques et politiques des Pays-Bas autrichiens. (Neuchatel, 1784), 347.

37 E. DEFACQZ, o.c., I, 58-59.

38 Het Rijksarchief in de Provinciën. I. De Vlaamse Provinciën. (Brussel, 1975), 183.

39 J.E. NEVE, Gand sous l'occupation de Louis XIV. 1678-1679, I7011706, 1708. (Gent, 1929), 324. Ph. KERVYN DE VOLKAERSBEKE, La capitulation de Gand de 1709. In Messager des sciences historiques de Belgique, 1875, 429 en 474. 


\section{P. LENDERS}

krijgsmacht van Lodewijk XIV op 5 juli 1708 vaardigde de Anglo-Bataafse Conferentie in naam van onze vorst Karel III (later Karel VI) bij wijze van bestraffing en sanctie een ordonnantie uit, die de rechtbank schorste. Haar jurisdictie werd overgedragen aan de luitenant-civil van Dendermonde, stad die nog in handen was gebleven van de coalitie. Alleen daar konden de Gentse poorters hun dagvaarding wettelijk deponeren ${ }^{40}$. Het baart dan ook geen opzien dat bij hun capitulatie op 1 januari 1709 de Gentenaars de reïnstallatie van de vorstelijke rechtbank van de indaginghe op hun verlangenslijstje hadden gezet.

Die houding stak nochtans schril af tegen de positie, die zij aannamen tegen een andere rechtbank van gedelegeerde rechters, die haar in 1709 werd opgelegd en die het stadsbestuur inzake collaboratie voor de periode julidecember 1708 moest beoordelen. Die werd radikaal afgewezen omdat het om een rechtbank ging, die niet uit "natuurlijke rechters" bestond ${ }^{41}$.

In elk geval is van de Gentse rechtbank van de luitenant-civil een ruim archief bewaard. Het berust in het rijksarchief te Gent en telt circa 1200 nummers, waarvan er $\mathbf{4 7 2}$ ontleed zijn en op steekkaarten gebracht. $\mathrm{Er}$ bestaat een handschriftelijke inventaris ${ }^{42}$. Ook in het Gentse stadsarchief vindt men nog een waardevol bestand in de reeksen 5 bis en 5ter. Het zijn veelal documenten uit de achttiende eeuw ${ }^{43}$. In het algemeen rijksarchief te Brussel vind men in de bestanden van de collaterale raden hier en daar sporen van de Vlaamse instellingen van de indaginghe: zo in de Raad van State $\mathrm{nr}$. 183 gegevens over de kandidaten, die zich voor een aanstelling aanmeldden en in de Geheime Raad nr. 468 en de Raad van Financiën nr. 3915 over de geboden koopsommen. Van de archivalia van de rechtbank van de Dendermondse luitenant-civil is heel weinig overgebleven. Het stadsarchief brandde in 1914 uit. Alleen het archief van Land en Leenhof van Dendermonde, dat in het rijksarchief van Beveren-Waas berust, bevat nog enkele stukken o.m. de nrs. 258-259 met procesbundels uit 1761-1777 44.

De rechtbanken van indaginghe blijken een weldaad geweest te zijn voor de economische ontwikkeling van Gent en werden uiteindelijk minder als sanctie dan als hulp ervaren.

40 O.P.B.A., II (Brussel, 1867), 169: Ordonnantie 9 augustus 1708.

41 J.E. NEVE, o.c., 172-175.

42 Het Rijksarchief in de Provinciën. I, 183.

43 J. DECAVELE \& J. VANNIEUWENHUYSE, Stadsarchief Gent. Archiefgids. I (Gent 1983) 35 en 77.

44 Met onze oprechte dank aan de stadsarchivaris van Dendermonde, Dr. A. Stroobants, voor de informatie betreffende de archivalia van de stedelijke kamer van indaginghe. 